\title{
Effect of different inoculum levels of Rhizoctonia solani kuhn. on disease development and growth of chilli (C. annuum) cv. G-4
}

\author{
RAHUL KUMAR SHARMA*, DEVESH PATHAK AND VAIBHAV PRATAP SINGH \\ Department of Plant Protection, Faculty of Agricultural Sciences, Aligarh Muslim University, ALIGARH (U.P.) INDIA \\ (Email : devpathak58@gmail.com)
}

\section{ARITCLE INFO}

Received : 10.04 .2017

Revised : 28.08 .2017

Accepted : 10.09 .2017

\section{KEY WORDS :}

Rhizoctonia solani, Chilli, Inoculums density, Growth, Disease development

*Corresponding author:

Email : rahulsharma10893@gmail.com

\begin{abstract}
Chilli (Capsicum annuum) is one of the most important spice crop in the world having nutritive value especially rich in Vitamin C. It suffers excess yield loss by the infection of root rot caused by Rhizoctonia solani worldwide. The present study was conducted to determine the effect of different inoculum levels of $R$. solani on growth and disease development of chilli cv. G-4 under pot conditions. The observations of this study revealed that $R$. solani is a potential pathogen, significantly reduced the length, fresh and dry weight of shoot and root of chilli cv. G-4 and increase root infection upto 5-65.7 per cent. The highest reduction in shoot length $(27.5 \%)$, root length $(10.3 \%)$, shoot fresh weight (15.5\%), root fresh weight (4.3\%), shoot dry weight $(6.7 \%)$ and root dry weight $(1.3 \%)$ were observed at highest inoculum level of $4 \mathrm{~g}$ culture $/ \mathrm{kg}$ soil. However, highest root infection (65.7\%) was observed at highest inoculum level i.e. $4 \mathrm{~g}$ culture/ $\mathrm{kg}$ soil,while root infection was least $(5.0 \%)$ at lowest inoculum level i.e. $0.5 \mathrm{~g}$ culture/ $\mathrm{kg}$ soil.
\end{abstract}

How to view point the article : Sharma, Rahul Kumar, Pathak, Devesh and Singh, Vaibhav Pratap (2017). Effect of different inoculum levels of Rhizoctonia solani kuhn. on disease development and growth of chilli (C. annuum) cv. G-4. Internat. J. Plant Protec., 10(2) : 375-377, DOI : 10.15740/HAS/IJPP/10.2/375-377. 